\title{
The influence of sex hormones on ASP production and C5L2 and adipogenesis related gene expressions in ovariectomized rats $e x$ vivo adipose tissue explant culture
}

\author{
B. Al Riyami, S. Langley-Evan and A. Salter \\ Division of Nutritional Sciences, School of Biosciences, University of Nottingham, Nottingham, UK
}

Acylation Stimulating Protein (ASP) is a hormone produced by adipose tissue that exhibits lipogenic properties. It enhances triacylglycerol (TG) uptake and postprandial TG clearance ${ }^{1}$. Progesterone has been shown to stimulate ASP -mediated TG clearance $^{2}$. Addition of chylomicrons to the media of cultured adipocytes also stimulates ASP production ${ }^{3}$. The aim of the present study was to investigate the effect of sex hormones on ASP production, in the absence and presence of chylomicrons, in ex vivo adipose tissue explants isolated from ovariectomized rats.

Adipose tissue explants $(n=6)$ were incubated with physiological levels of progesterone, estrogen, progesterone \& estrogen $(\mathrm{P} \& \mathrm{E})$ and testosterone for 24 hours at $37^{\circ} \mathrm{C}$ in the absence or presence of chylomicrons. Media ASP was measured by ELISA and results are presented as mean $\pm \mathrm{SEM}$ with significant differences set at $* \mathrm{P}<0.05$ using Dunnett $\mathrm{t}$ post hoc analysis.

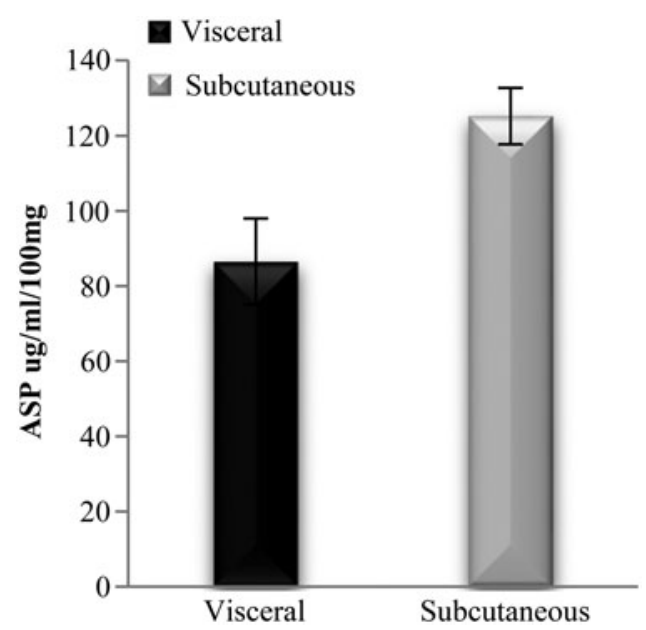

Fig. 1. ASP levels in the control group

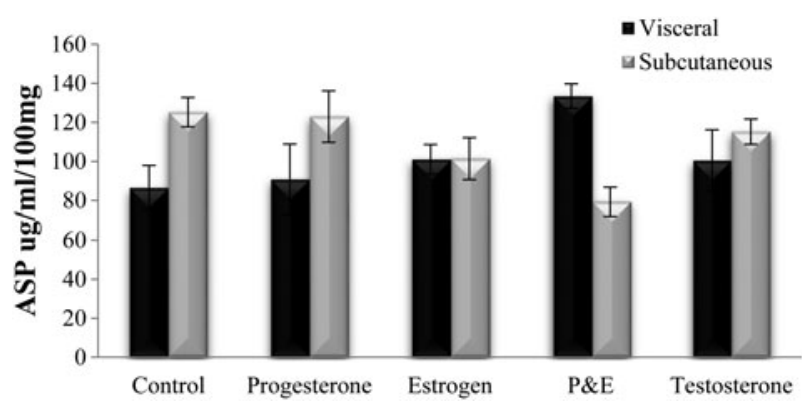

Fig. 2. ASP levels with different hormone treatments

In the absence of hormones, ASP concentrations in the explant media were higher in subcutaneous than visceral tissue (Fig.1, $\mathrm{P}=0.026)$. In the presence of chylomicrons, hormone treatment significantly affected ASP level in media from visceral $(\mathrm{F}(4,78)=$ 6.41, $\mathrm{P}<0.001)$ and subcutaneous tissue $\left(\mathrm{F}_{(4,81)}=3.92, \mathrm{P}=0.006\right)$. Post hoc analysis showed a significant increase in $\mathrm{P} \& \mathrm{E}$ group compared to control groups (Fig. 2, $\mathrm{P}=0.006$ ) in the visceral adipose tissue explant cultures. The same group showed a significant reduction of ASP level in subcutaneous explant media (Fig. 2, P=0.004). Hormones had no significant effect in the absence of chylomicrons (data not shown).

The higher ASP concentrations in media from in the subcutaneous tissue explants agrees with previous findings that ASP stimulates TG synthesis to a greater extent in subcutaneous adipocytes ${ }^{4}$. The combination of P\&E has opposite effects, depending on adipose tissue depot. Further analysis of related gene expression will explore whether this is the result of the changes in production or increased uptake of ASP into adipocyte through its receptor.

AA-R was supported by a PhD studentship from the Omani government.

1. Cianflone K, Xia Z and Chen LY (2003) Bio et Biophysica Acta 1609, 127-143.

2. Al Riyami B, El Tahir M, Al Maskari S et al. (2014) J of Nutri and Metab 2014, ID 510916.

3. Scantlebury T., Maslowska M and Ciaflone K (1998) J Biol Chem 273, 20903-20909.

4. Walsh MJ, Sniderman AD, Cianflone K et al. (1989) J Surgi Res 46, 470-3. 